\title{
Impact of selected determinants on the financial structure of the mining companies in the selected countries
}

\author{
Nicole Škuláňová ${ }^{1}$
}

\begin{abstract}
Investigating the effects on the capital structure has been a widely debated topic for over a century. There are countless studies on this subject today. However, there is still a need to test more samples of companies, as the confirmation or rebuttal of assumptions depends on the industry, country, and size of the selected company. This research deals with the impact of five selected determinants - profitability, asset structure, non-debt tax shield, GDP growth rate, inflation, on the total, long-term and shortterm debt of mining companies from eleven selected economies - eight countries from Central and Eastern Europe and three industry leaders from non-European countries. The analysis of data obtained from Orbis and the World Bank database covers the period 2009-2017. Correlation analysis and GMM methods are used to detect the dependencies of variables. Many countries show some links to selected types of debt. Some of these links are in line with the input assumptions, some unfortunately not.
\end{abstract}

Keywords: asset structure, depreciation, financial structure, GDP, inflation, profitability.

JEL Classification: G32

\section{Introduction}

The financial structure of a company means, among others, the structure of financial sources, which is used to finance company assets and business activities. Unlike the capital structure, the financial structure also includes short-term sources of financing. Sources for funding can be divided into different ways: own and foreign, internal (retained profit) and external (share and bond issues, credit), long-term and short-term. Deciding on the form of a financial structure is one of the core activities of a business manager since the structure of sources of financing is linked to the profitability and risk of the business.

The issue of the capital structure began to be discussed at the beginning of the last century. Still, it came to the attention of the study of Modigliani and Miller (1958), "The Cost of Capital, Corporation Finance and the Theory of Investment." The authors state that in perfect capital markets and the absence of taxes, the company's indebtedness is not linked to its value and the cost of capital. Several others studies and theories have

\footnotetext{
${ }^{1}$ Silesian University in Opava, School of Business Administration in Karvina, Univerzitní nám. 1934/3, 73340 Karvina, Czech Republic; email: skulanova@opf.slu.cz

(C) 2020 by the authors; licensee Review of Economic Perspectives / Národohospodárský obzor, Masaryk University, Faculty of Economics and Administration, Brno, Czech Republic. This article is an open access article distributed under the terms and conditions of the Creative Commons Attribution 3.0 license, Attribution - Non Commercial - No Derivatives.
} 
emerged from this study, resulting in further theories of capital structure. Two main approaches are considered: the trade-off theory (Brealey et al., 2011), which seeks optimum through a balance between the costs of financial distress and the tax shield; and the pecking order theory (Myers, 1984), which advocates that companies prefer their sources of financing over foreign ones.

Decision-making on the capital structure has become such an important activity that economists are still discussing and creating new models, formulas, and determinants to explain the specific decisions of businesses why they use particular sources of financing for their activities.

The authors of the first studies often examined large companies that were listed on the stock exchanges. They also chose companies from developed countries such as Great Britain, Germany, the United States. Only in recent years, the examined samples include companies from many countries such as Nepal (Gajurel, 2006), Latin American countries (Bastos et al., 2009), Iran (Salehi and Manesh, 2012), India (Handoo and Sharma, 2014), Bosnia and Herzegovina (Bajramović, 2017), Nigeria (Yinusa et al., 2017), Vietnam (Vo, 2017), Thailand, Indonesia, and Malaysia (Mursalim and Kusuma, 2017).

This research aims to determine the influence of selected determinants on the financial structure of mining companies in eleven selected economies. Within this objective, three research hypotheses were developed for three forms of indebtedness, whose validity will be tested using correlation and regression.

- $\mathrm{H}_{1}$ : For total debt is expected negative link with profitability, non-debt tax shield and inflation; positive link with asset structure and GDP growth.

- $\mathrm{H}_{2}$ : For long-term debt is expected negative link with profitability, non-debt tax shield and inflation; positive link with asset structure and GDP growth.

- $\mathrm{H}_{3}$ : For short-term debt is expected negative link with profitability, asset structure, non-debt tax shield, GDP growth; positive link with inflation.

The contribution of this article is in the size of the examined sample, which includes over 19,000 companies from the eleven selected countries that are tested individually and not in an aggregate panel as usual. The contribution of the research is also a motivation for this research. The author deals with this area and lacks studies for selected countries of Central and Eastern Europe. Therefore, it is an incentive to contribute to the extension of knowledge so that future studies have more studies available than is currently available.

This paper is organized as follows. Section 1 outlines earlier studies on the financial structure and their determinants suggested by these studies. Section 2 presents the research methodology, data, and variables and provides a description of the industry and examined economies. Section 3 describes the results of the analysis of variable dependencies. Section 4 presents the conclusions.

\section{Overview of literature}

In shaping financial strategies on how to finance business activities, managers are influenced by some determinants, which can be divided into in-company and noncompany. This research has representatives from both these groups. Specifically, the subject of the study is five selected determinants - profitability, asset structure, 
non-debt tax shield, macroeconomic development, and inflation. In the following part, the authors' surveys and knowledge of these factors will be analysed. Given that the research is concerned with the extended Visegrád Group (V4 + Bulgaria, Romania, Austria, Slovenia), among other things, it is crucial to mention studies that have studied these countries, since for some determinants these countries tend to have different outcomes than usual.

The essential determinant, which is the content of many studies and among the incompany factors, is profitability. The effect of profitability on the level of debt differs according to two basic theories. The trade-off theory works with the costs of financial distress, and it is precisely because of their existence that more profitable companies should have less risk of bankruptcy and hence lower costs of financial distress, so lenders should be willing to lend more and indebtedness may increase. (Brealey et al., 2011) On the other hand, the main idea of the pecking order theory is the preference of internal funding sources such as retained earnings. If profitability increases, this profit can grow, and the company will finance its activities with its origins and will no longer borrow. (Myers, 1984) The second theory has been confirmed by far more authors such as Rajan and Zingales (1995), Gaud et al. (2003), De Jong et al. (2008), Kayo and Kimura (2011), Öztekin (2015). Also, when divided into three forms of debt - total, long-term, short-term (the same division will be in this article), the resulting profitability impacts remain the same, as approved by Michaelas et al. (1999), Song (2005), Handoo and Sharma (2014). In the countries of the extended Visegrád Group, the results are thus not clearly in favour of negative links. A number of studies have also revealed a positive link e.g., Klapper et al. (2002), Pinková (2012), Aulová and Hlavsa (2013), Mokhova and Zinecker (2013) and Růčková (2015a, 2015b, 2017).

Another determinant is tangibility, which is usually expected to have a positive relationship with the level of debt. This linkage is because tangible assets can be used as collateral in lending, providing greater protection for the lender. The studies by Stulz and Johnson (1985) and Titman and Wessels (1988) offer a different point of view, namely that intangible assets are complicated to sell in the event of bankruptcy or financial problems; usually, it is necessary to sell the whole company or just intangible assets, but certainly with a loss. Intangible assets include, for example, trademarks, customer lists, non-compete agreements, patents, employment contracts, etc. It is obvious that such assets are difficult to assess for sale, which will always be with a loss. Even though it is clear from what has been said so far, what link, in which case, there are several pitfalls that change expected links - the orientation of the country's financial system (collateral is typically used in bankingoriented systems), the sector that we will focus on (stocks cannot be used as collateral), size of the company (micro and small not have a significant amount of tangible assets) and dividing debt into short-term and long-term (tangible assets are usually used as collateral in long-term lending). This relationship was examined, for example, in these studies - Michaelas et al. (1999), Klapper et al. (2002), Weill (2004), Bokpin (2009), Aulová and Hlavsa (2013), Mokhova and Zinecker (2013), Onofrei et al. (2015), Růčková (2015a).

The third determinant is the non-debt tax shield in the form of depreciation, which should replace tax benefits and thus help reduce debt. Michaelas, Chittenden, and 
Poutziouris (1999) for long-term debt, Wald (1999), Klapper et al. (2002), Song (2005) for long-term debt, Hernádi and Ormos (2012), and Acedo-Ramirez and Ruiz-Cabestre (2014) found a negative link. However, even with this factor, negative binding is not the only possible, and there may be a case of positive binding. In their study, Acedo-Ramirez and Ruiz-Cabestre (2014) argue that a positive link can occur if depreciation is more or less equal to the number of tangible assets that can be used as collateral, favoring rising debt rather than falling. At the same time, differences in tax regulations in the countries under review can be a positive link, such as Delcoure (2007), Hernádi and Ormos (2010), Aulová and Hlavsa (2013) and Mokhova and Zinecker (2013).

The remaining two variables characterize the impact of the external environment on the financial structure of enterprises. As for the impact of GDP and inflation on the level of debt, the study does not agree here either. In the case of GDP, the ambiguity can be explained by the fact that if, for example, the expansion increases the profitability of companies, so on the one hand, the probability of bankruptcy decreases, making creditors more willing to lend. On the other hand, as profit grows, also retained profit can grow, which is a suitable own source of financing and so the company does not have to indebt. With regard to inflation, its growth causes a reduction in debt owing to a decline in the real interest rate and, on the one hand, companies may consequently become more indebted (at the expense of cheap debt) or existing debt is falling, causing a negative link. These determinants are dealt by e.g., Gajurel (2006), Cheng and Shiu (2007), Bastos et al. (2009), Bokpin (2009), Sett a Sarkhel (2010), Salehi a Manesh (2012), Mokhova and Zinecker (2014), Mursalim a Kusuma (2017), Huong (2018).

\section{Data and methodology}

The subject of the research is companies from 11 selected countries, which are classified according to the NACE statistical classification into section B - mining and quarrying. The sample examined includes all companies in the Orbis database. The selected countries are Czech Republic (CZ), Slovakia (SK), Poland (PL), Hungary (HU), Austria (AT), Slovenia (SI), Romania (RO), Bulgaria (BG), United States (US), Canada (CA), Australia (AU). This research compares the countries of the extended Visegrád Group and the three states that own the largest mining companies in the world and are leaders in the industry. The countries of Central and Eastern Europe were selected for efforts to broaden the existing knowledge of the financial structure in these latitudes. The extended Visegrád Group included V4 and Austria, Bulgaria, Slovenia, and Romania. These countries have been added as they are often associated with the V4, and the representatives of these countries often participate in the V4 negotiations. Comparison with industry leaders should show whether there is a different impact of determinants on the financial structure of companies. A total of 19,530 companies were found in the database for the period 2009-2017 (without distinction between the raw materials they extract; it is a comparison of entire mining sectors, not of specific subsectors).

This research aims to determine the influence of selected determinants on the financial structure of mining companies in eleven selected economies. Based on a review of earlier studies mentioned above, the following hypotheses are expected: 
1. H1: For total debt is expected negative link with profitability, non-debt tax shield and inflation; positive link with asset structure and GDP growth.

2. H2: For long-term debt is expected negative link with profitability, non-debt tax shield and inflation; positive link with asset structure and GDP growth.

3. H3: For short-term debt is expected negative link with profitability, asset structure, non-debt tax shield, GDP growth; positive link with inflation.

\section{Variables}

Selected variables discussed below were chosen with regard to the frequency of occurrence in previous researches. The debt-equity ratio, profitability, and asset structure often occur, and this article is intended to confirm the assumptions made so far. Conversely, the remaining variables are not so often the subject of research, and therefore there is scope to expand knowledge.

For variables, the dependent variable is represented by three forms of debt. The first is the debt-equity ratio (DER) for total debt, defined as the ratio of total liabilities to equity. The remaining two dependent variables are for long-term (DER_L) and short-term debt (DER_S). Compared to the first share, it differs in that the numerator has either only long-term or only short-term liabilities.

Independent variables are represented by selected determinants that affect the capital structure. The first variable is profitability, which in this case is represented by the return on assets (ROA) - i.e., the ratio of profit before tax and interest and total assets. There are several indicators for expressing the structure of assets (SA); in this research, the share of tangible fixed assets and total assets is used. The non-debt tax shield (DEPR) is expressed as a proportion of depreciation and total assets. The impact of economic development is represented by the GDP growth rate at market prices. The last variable is inflation (INF) measured by the inflation rate.

\section{Methodology}

Many methods can be used to analyse the interdependencies between debt and determinants. The primary and frequently used method is correlation analysis, whose resulting coefficient should be in the range from -1 to 1 . If the value approaches -1 , the resulting dependence is negative; a value close to 1 indicates a positive dependence. Values around 0 indicate no relationship between variables. In this research, the Pearson correlation coefficient has the following equation:

$$
\rho_{X Y}=\frac{\operatorname{cov}\left(X_{i}, Y_{j}\right)}{\sigma_{X} \sigma_{Y}}
$$

Another widely used method is some form of regression. Due to a large number of companies and determinants in the examined sample, panel regression should be used, as panels that are formed by determinants create a more dynamic model while simultaneously monitoring firm heterogeneity. However, a simple panel regression is not appropriate due to the short time series, the ambiguity of the results, and the need for stationary data (Průcha, 2014). Therefore, a two-stage Generalized Method of Moments (GMM) system by Arellano and Bond (1991) is used herein. Short time series can be used in this model, error correlation control exists, non-stationary data can be used, the delayed value of the dependent variable is included, and strict exogenous variables need 
not be included. The disadvantage of this model is that heteroscedasticity and autocorrelation of variables cannot be tested. Therefore, a robustness test, such as the Sargan test is required for the relevance and credibility of the results. This test should show to what extent the method is able to give almost the same results in a given model even if we slightly change the parameters. A model can be considered robust if the result of this test is greater than 0.05 . The model parameters for this research are as follows:

$$
\begin{aligned}
D E R_{i t}= & \alpha_{0}+\beta_{1} * D E R_{i t-1}+\beta_{2} * R O A_{i t}+\beta_{3} * S A_{i t}+\beta_{4} * \\
& D E P R_{i t}+\beta_{5} * G D P_{i t}+\beta_{6} * I N F_{i t}+\varepsilon_{i t} ;
\end{aligned}
$$

where symbols $\alpha$ and $\varepsilon$ denote a constant and a random component of the model that represents all other influences that may affect the financial structure and cannot be overlooked. Other variables have been described above - individual determinants and three forms of debt. Last but not least, the equation also contains a delayed value of the dependent variable $\left(\mathrm{DER}_{\mathrm{it}-1}\right)$, which allows the modelling of the partial adaptation mechanism in a dynamic model. Since the data used will be at an annual frequency, the delay will also be one year.

Stationary series were used for both analyses to be based on the same conditions as stationary data are required for correlation. Only two time series did not fulfil the stationarity tests, namely inflation for the Czech Republic and Slovenia.

The following table shows the expected effects of individual determinants and forms of debt:

\section{Table 1. Expected effects}

\begin{tabular}{lccccc} 
& ROA & SA & DEPR & GDP & INF \\
\hline DER & - & + & - & + & - \\
DER_L & - & + & - & + & - \\
DER_S & - & - & - & - & + \\
\hline rce: Author's expectations based on earlier studies.
\end{tabular}

\section{Characterization of the mining industry}

This research is devoted to companies belonging to Section B according to the NACE statistical classification, i.e., mining and quarrying. Mining includes raw materials in all states - solid such as coal and ores, a liquid such as oil, or gaseous such as natural gas. Mining is carried out underground, underwater, using boreholes, or on the surface. Mineral resources are unevenly distributed, and therefore, some economies have more stocks of these resources than other economies. Countries that have mineral wealth either export it (Russia, the Persian Gulf oil states) or conserve it (the United States). However, many countries are dependent on imports of certain primary raw materials, with $\mathrm{Japan}^{2}$ being the typical representative.

Representation of companies in individual countries can be seen in Table 1, which also shows the number of companies in each division of the industry. Most companies have

\footnotetext{
${ }^{2}$ https://oec.world/en/profile/country/jpn/\#Imports [accessed on $31^{\text {st }}$ January 2020]
} 
American roots. However, despite the disparity between companies in the United States, Canada, Australia and the rest of the countries, it makes sense to investigate the impact of selected determinants on the financial structure, as countries are examined individually, and research aims to characterize industries in each state rather than generalize industry conclusions across all countries.

Table 2. Number of mining companies in individual divisions of the industry

\begin{tabular}{|c|c|c|c|c|c|c|c|c|c|c|c|}
\hline & $\mathrm{CZ}$ & SK & $\mathrm{PL}$ & $\mathrm{HU}$ & AT & SI & RO & $B G$ & US & $\mathrm{CA}$ & AU \\
\hline Mining of coal and lignite & 12 & 1 & 28 & 9 & 0 & 3 & 10 & 15 & 791 & 52 & 402 \\
\hline $\begin{array}{l}\text { Extraction of crude petro- } \\
\text { leum and natural gas }\end{array}$ & 3 & 1 & 23 & 14 & 11 & 0 & 25 & 5 & 3346 & 1195 & 413 \\
\hline Mining of metal ores & 1 & 3 & 6 & 3 & 0 & 1 & 16 & 15 & 504 & 680 & 608 \\
\hline Other mining and quarrying & 123 & 53 & 364 & 66 & 66 & 31 & 191 & 103 & 1680 & 597 & 867 \\
\hline $\begin{array}{l}\text { Mining support service } \\
\text { activities }\end{array}$ & 22 & 5 & 74 & 25 & 7 & 4 & 58 & 11 & 4959 & 1424 & 604 \\
\hline$\Sigma$ & 161 & 63 & 495 & 117 & 84 & 39 & 300 & 149 & 11280 & 3948 & 2894 \\
\hline
\end{tabular}

Source: Author's calculations based on data from database Orbis.

This sector includes mining of coal and lignite, extraction of crude petroleum and natural gas, mining of metal ores, other mining and quarrying (stone, sand, clay, peat, salt, chemical and fertilizer minerals, kaolin, chalk, gypsum, gravel) and mining support service activities.

As mentioned in the previous chapter, the research examines eleven selected economies - the extended Visegrád Group and the United States, Canada, Australia. The last three countries were chosen because they were founded one of the largest mining companies in the world: BHP Billiton, Rio Tanto and Fortescue Metals (Australia), FreeportMcMoRan, Southern Cooper, Newmont and Alcoa (United States), Barrick Gold, Goldcorp, PotashCorp, Agrium (Canada).

For economic comparison is used The Mining Contribution Index ${ }^{3}$, which compares 182 countries in terms of mining dependence as the primary driver of economic activity. The ranking according to MCI in 2018 was as follows: Australia 32., Bulgaria 53., Canada 66., Poland 82., United States 101., Romania 115., Hungary 120., Austria 122., Slovakia 139., Czech Republic 141. and Slovenia 156.

The mining industry is a cyclical sector, and its development is closely related to commodity prices and demand. Looking at individual commodity charts or the MSCI World Metals and Mining Index ${ }^{4}$, it is clear that the industry has been growing steadily by 2009. In 2007 and 2008, an enormous amount of new orders was even achieved, and the sector's debt was $100 \%$; also, commodity prices were high. This boom ended with the

\footnotetext{
${ }^{3}$ https://www.icmm.com/website/publications/pdfs/social-and-economicdevelopment/181002_mci_4th-edition.pdf [accessed on 12 ${ }^{\text {th }}$ August 2019]

${ }^{4}$ https://www.msci.com/documents/10199/fb6ddbdf-8df3-4fdf-96b4-e578e2ac776c [accessed on $12^{\text {th }}$ August 2019]
} 
financial crisis in 2009 when the MSCI index, as mentioned above, plummeted; commodity prices recognized new bottoms, mergers, and acquisitions began. As a result, debt also fell to less than $80 \%$, as can be seen in Table 2. In the next two years, the expansion began again, with commodity prices rising. However, in 2011 the trend reversed, and since then, prices have been falling slowly until 2015 when prices of some raw materials have reached new bottoms (e.g., nickel, oil, coal, iron ore). There were many reasons for this - the slowdown in the Chinese economy's growth and decline in demand, the depreciation of currencies, the discovery of new technologies (e.g., oil and shale gas extraction), new environmental standards, surplus raw material supply (e.g., oil, coal), new government policies (e.g., nickel), etc. Since 2015, the industry and commodity prices have started to recover slowly.

Table 2 shows the development of the debt-equity ratios in individual countries from 2009 to 2016 (note: the year 2017 is not included due to a more substantial amount of missing data, which would cause distortion). We can see that the whole sector was below $100 \%$ except for two years. Hungarian, Austrian, Slovenian, Romanian, American, and Australian companies were more or less over $100 \%$ all the time; some of them even far from this border.

Table 3. The debt-equity ratio of mining companies in selected countries

\begin{tabular}{ccccccccc} 
& 2009 & 2010 & 2011 & 2012 & 2013 & 2014 & 2015 & 2016 \\
\hline CZ & $40.22 \%$ & $34.59 \%$ & $37.78 \%$ & $44.52 \%$ & $56.74 \%$ & $48.80 \%$ & $47.25 \%$ & $36.87 \%$ \\
SK & $54.13 \%$ & $39.50 \%$ & $41.39 \%$ & $43.75 \%$ & $65.47 \%$ & $79.39 \%$ & $116.20 \%$ & $102.90 \%$ \\
PL & $60.21 \%$ & $61.33 \%$ & $53.68 \%$ & $73.09 \%$ & $68.54 \%$ & $75.52 \%$ & $87.21 \%$ & $115.34 \%$ \\
HU & $287.32 \%$ & $278.38 \%$ & $277.03 \%$ & $170.92 \%$ & $170.98 \%$ & $175.64 \%$ & $169.67 \%$ & $196.35 \%$ \\
AT & $111.85 \%$ & $195.57 \%$ & $130.39 \%$ & $133.46 \%$ & $149.82 \%$ & $155.41 \%$ & $164.10 \%$ & $162.90 \%$ \\
SI & $171.74 \%$ & $199.94 \%$ & $230.14 \%$ & $225.69 \%$ & $231.61 \%$ & $218.31 \%$ & $178.25 \%$ & $165.47 \%$ \\
RO & $165.31 \%$ & $187.43 \%$ & $169.50 \%$ & $97.86 \%$ & $87.07 \%$ & $122.78 \%$ & $2180.70 \%$ & $5144.47 \%$ \\
BG & $74.44 \%$ & $66.84 \%$ & $62.52 \%$ & $52.87 \%$ & $60.28 \%$ & $65.86 \%$ & $64.63 \%$ & $67.80 \%$ \\
US & $109.53 \%$ & $106.45 \%$ & $113.23 \%$ & $120.61 \%$ & $127.47 \%$ & $145.10 \%$ & $236.35 \%$ & $198.35 \%$ \\
CA & $84.81 \%$ & $75.92 \%$ & $88.68 \%$ & $83.81 \%$ & $91.42 \%$ & $96.60 \%$ & $108.21 \%$ & $94.79 \%$ \\
AU & $123.59 \%$ & $115.90 \%$ & $124.26 \%$ & $118.96 \%$ & $130.99 \%$ & $133.91 \%$ & $145.73 \%$ & $151.13 \%$ \\
\hline Sector & $79.19 \%$ & $69.60 \%$ & $73.36 \%$ & $82.55 \%$ & $98.73 \%$ & $104.83 \%$ & $119.04 \%$ & $92.49 \%$ \\
\hline
\end{tabular}

Source: Author's calculations based on data from database Orbis.

To analyse the results of the regression and correlation analysis, it is also necessary to show the structure of the debt of companies. It is this composition, on average, that is shown in Figure 1. We see that Slovak, Hungarian, Austrian, Bulgarian, American, Canadian, and Australian companies are using more long-term debt than short-term debt. 
Figure 1. Average long-term and short-term debt-equity ratio

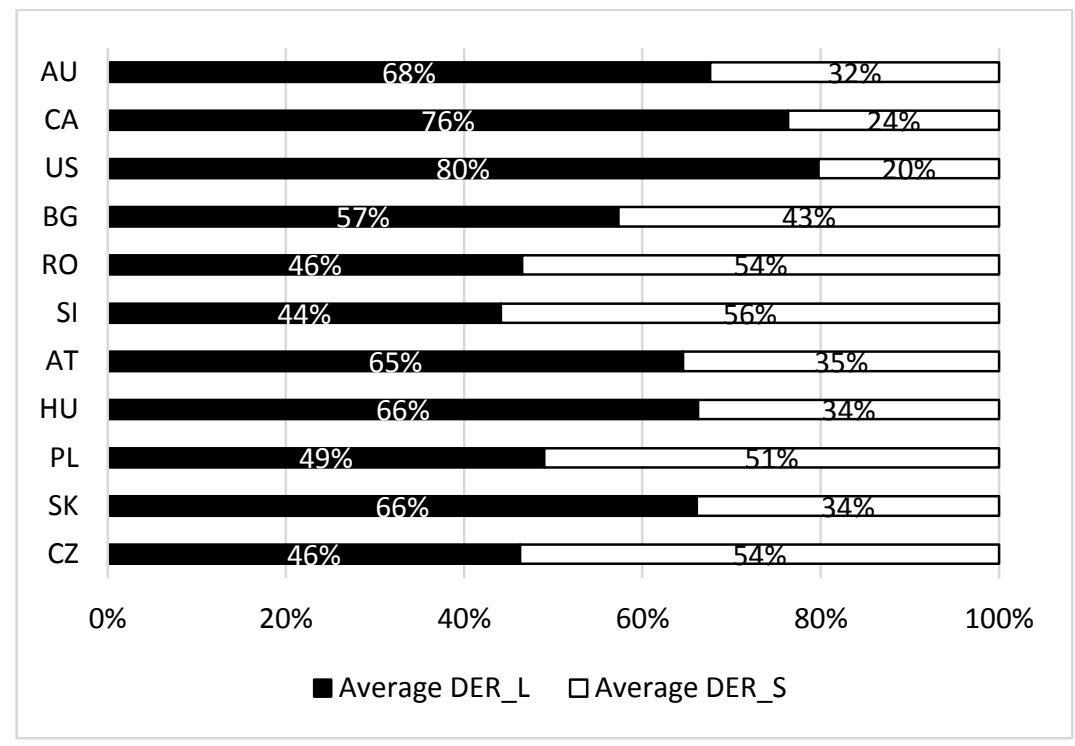

Source: Author's calculations based on data from database Orbis.

\section{Economic development of individual countries}

Given the diversity of the selected economies, it is appropriate to analyse their economic development from 2009 to 2017. Table 3 shows the development of GDP growth rates, and Table 4 shows the development of inflation rates in individual countries.

The Czech Republic is one of the more fortunate countries that was not hit hard by the global crisis in 2009. The table below shows that GDP has fallen, but it has not had any significant impacts. In the following year, the economy was growing again; growth continued until the turn of 2012 and 2013 when the Czech Republic was hit by the economic crisis, which was caused by a decline in household consumption and investment. Table 4 shows a decrease in the inflation rate in 2013 when the Czech National Bank also introduced exchange rate interventions because of the failure to meet the inflation target. These interventions lasted until 2017, when the inflation rate started to meet the inflation target. Since 2013, the development of the Czech economy has been more or less smooth.

Another country that emerged relatively well from the crisis is Slovakia, which owes the milder impact of the crisis to the insignificant stock exchange and the fixing of the exchange rate of its currency to the euro, as Slovakia entered the euro area in 2009. The decline in GDP of more than $6 \%$ was due to lower external demand and the structure of the industry, which is dominated by durable products such. In addition to this significant slump, GDP grew all the time, but in 2013 and 2016, the growth rate was more moderate. In 2013, it was due to lower domestic demand due to unemployment and government debt reduction policy; in 2016, this was due only to lower domestic demand. As far as the inflation rate is concerned, the inflation of the European Central Bank is not met in any one year, and Slovakia even reached deflation in 2014-2016. 
The Polish economy was not affected by the global or European debt crisis. GDP in 2009 even reached an incredible $6.7 \%$ and continued to grow in the years to come. This situation was also aided by the fact that it is a large economy under the extended V4 (more EU financial sources), but it is also a relatively closed economy with a large internal market. Crisis avoidance has also been contributed to by co-organizing the 2012 European Football Championship, which has made significant infrastructure investments. Not only the GDP was high, but the inflation rate was also slightly higher in 2009-2012. These values are due to higher food and energy prices (linked to oil prices), the devaluation of the Polish zloty and the increase in VAT rates in 2011. From 2014 to 2016, the Polish economy was in deflation due to cheaper food due to a ban on imports of certain types of food to Russia.

Within the core Visegrád Group, Hungary suffered the worst of the crisis, reaching the IMF loan application. The reasons why the Hungarian economy turned out badly are several - poor government management, high debt, focus on exports. Unfortunately, in this case, the crisis also had a severe impact on the general population, as people at that time had mortgages and loans in currencies other than the forint, which was considerably more expensive at the time of the crisis. While the government has introduced reforms to help the economy, growth slowed slightly in 2012 due to lower domestic demand, reduced disposable income of the population, declining investment in industry, and losses in agriculture. Since 2013, the economy has been growing at an incredible pace; for example, in 2017 , the growth was already $8.12 \%$. This growth is due to EU funds, increased domestic consumption, the prosperity of the construction industry.

The Austrian, Slovenian, and Romanian economies were also hit by the crisis in 2009 . The first economy recorded a decline in GDP of less than $4 \%$, an increase in unemployment, government deficit, and debt, which exceeded $70 \%$. The Austrian government was forced to launch a deposit guarantee, and at the same time, it has allocated over one hundred billion euros to stabilize the banking system. After the crisis year, the GDP growth rate rose and then declined to just $0.03 \%$ in 2013; since that year, the pace of growth has started to grow again, and the economy has recovered slowly. The inflation rate declined during the period under review and subsequently increased with an average of around $1.7 \%$.

As regards the latter, before the crisis, the Slovenian economy showed a solid rate of growth, which was caused by a significant amount of investment in the real estate sector. Unfortunately, this has resulted in a bubble in this sector that burst as soon as the bubble burst in the United States. Like them, the Slovenian boom was financed by bank loans, which became problematic after the bubble, and Slovenia went into the banking crisis in 2013, which can be seen in the decline in GDP in 2012 and 2013. The banking crisis was made possible mainly by the fact that most Slovenian banks were state-owned. It is not unusual that state banks are often poorly managed and ignore as much risk as may arise. This crisis has also brought high unemployment (around $10 \%$ ), a vast government deficit close to $15 \%$ and, as in Austria, the state debt has even exceeded $70 \%$. It must be said that the Slovenian government did not apply for any loan, as was customary, and managed to calm the situation through reforms. The inflation rate in Slovenia was on average low over the period 2009-2017. In 2015 and 2016, there was even deflation, which is visible in some countries in Table 4. This situation is due, among other things, to a decline in energy prices. 
Table 4. GDP growth development in individual countries

\begin{tabular}{cccccccccc} 
& 2009 & 2010 & 2011 & 2012 & 2013 & 2014 & 2015 & 2016 & 2017 \\
\hline CZ & $-2.33 \%$ & $0.82 \%$ & $1.80 \%$ & $0.65 \%$ & $0.94 \%$ & $5.26 \%$ & $6.54 \%$ & $3.75 \%$ & $5.81 \%$ \\
SK & $-6.52 \%$ & $5.55 \%$ & $4.51 \%$ & $2.94 \%$ & $2.02 \%$ & $2.59 \%$ & $4.01 \%$ & $2.64 \%$ & $4.46 \%$ \\
PL & $6.70 \%$ & $5.33 \%$ & $8.41 \%$ & $4.00 \%$ & $1.69 \%$ & $3.83 \%$ & $4.64 \%$ & $3.38 \%$ & $6.86 \%$ \\
HU & $-2.83 \%$ & $3.03 \%$ & $3.97 \%$ & $1.68 \%$ & $5.10 \%$ & $7.72 \%$ & $5.51 \%$ & $3.19 \%$ & $8.12 \%$ \\
AT & $-3.76 \%$ & $1.84 \%$ & $2.92 \%$ & $0.68 \%$ & $0.03 \%$ & $0.66 \%$ & $1.14 \%$ & $2.04 \%$ & $2.55 \%$ \\
SI & $-7.80 \%$ & $1.24 \%$ & $0.65 \%$ & $-2.67 \%$ & $-1.13 \%$ & $2.98 \%$ & $2.26 \%$ & $3.15 \%$ & $5.00 \%$ \\
RO & $-5.91 \%$ & $-2.81 \%$ & $2.01 \%$ & $2.08 \%$ & $3.51 \%$ & $3.41 \%$ & $3.87 \%$ & $4.80 \%$ & $7.26 \%$ \\
BG & $-3.59 \%$ & $1.32 \%$ & $1.91 \%$ & $0.03 \%$ & $0.49 \%$ & $1.84 \%$ & $3.47 \%$ & $3.94 \%$ & $3.81 \%$ \\
US & $-2.78 \%$ & $2.72 \%$ & $1.55 \%$ & $2.25 \%$ & $1.84 \%$ & $2.45 \%$ & $2.88 \%$ & $1.57 \%$ & $2.22 \%$ \\
CA & $-2.95 \%$ & $3.08 \%$ & $3.14 \%$ & $1.75 \%$ & $2.32 \%$ & $2.86 \%$ & $0.67 \%$ & $1.10 \%$ & $2.99 \%$ \\
AU & $1.94 \%$ & $2.07 \%$ & $2.46 \%$ & $3.90 \%$ & $2.62 \%$ & $2.57 \%$ & $2.34 \%$ & $2.85 \%$ & $2.34 \%$ \\
\hline
\end{tabular}

Source: World Bank database.

The third economy was hit hard by the crisis. Romania was another country that was forced to apply for an IMF loan, which eventually amounted to twenty billion euros. The purpose of the loan was to strengthen foreign exchange reserves and kick-start the credit market. In terms of GDP growth, the economy shrank from the crisis, reaching growth of $7 \%$ in 2017. As regards the evolution of the inflation rate, it was, on average, over $4 \%$ over the period 2009-2014. Deflation occurred in 2015 and 2016, which has the same cause as mentioned above.

The last country in the extended V4 is Bulgaria, which has not been severely affected by the crisis. As a result, unemployment and government deficits have increased, but today, everything is reaching acceptable levels.

Table 5. Inflation rate development in individual countries

\begin{tabular}{cccccccccc} 
& 2009 & 2010 & 2011 & 2012 & 2013 & 2014 & 2015 & 2016 & 2017 \\
\hline CZ & $1.02 \%$ & $1.47 \%$ & $1.92 \%$ & $3.29 \%$ & $1.44 \%$ & $0.34 \%$ & $0.31 \%$ & $0.68 \%$ & $2.45 \%$ \\
SK & $1.62 \%$ & $0.96 \%$ & $3.92 \%$ & $3.61 \%$ & $1.40 \%$ & $-0.08 \%$ & $-0.33 \%$ & $-0.52 \%$ & $1.31 \%$ \\
PL & $3.80 \%$ & $2.58 \%$ & $4.24 \%$ & $3.56 \%$ & $0.99 \%$ & $0.05 \%$ & $-0.87 \%$ & $-0.66 \%$ & $2.08 \%$ \\
HU & $4.21 \%$ & $4.86 \%$ & $3.93 \%$ & $5.65 \%$ & $1.73 \%$ & $-0.23 \%$ & $-0.06 \%$ & $0.39 \%$ & $2.35 \%$ \\
AT & $0.51 \%$ & $1.81 \%$ & $3.29 \%$ & $2.49 \%$ & $2.00 \%$ & $1.61 \%$ & $0.90 \%$ & $0.89 \%$ & $2.08 \%$ \\
SI & $0.84 \%$ & $1.80 \%$ & $1.80 \%$ & $2.60 \%$ & $1.77 \%$ & $0.20 \%$ & $-0.53 \%$ & $-0.05 \%$ & $1.43 \%$ \\
RO & $5.59 \%$ & $6.09 \%$ & $5.79 \%$ & $3.33 \%$ & $3.98 \%$ & $1.07 \%$ & $-0.59 \%$ & $-1.54 \%$ & $1.34 \%$ \\
BG & $2.75 \%$ & $2.44 \%$ & $4.22 \%$ & $2.95 \%$ & $0.89 \%$ & $-1.42 \%$ & $-0.10 \%$ & $-0.80 \%$ & $2.06 \%$ \\
US & $-0.36 \%$ & $1.64 \%$ & $3.16 \%$ & $2.07 \%$ & $1.46 \%$ & $1.62 \%$ & $0.12 \%$ & $1.26 \%$ & $2.13 \%$ \\
CA & $0.30 \%$ & $1.78 \%$ & $2.91 \%$ & $1.52 \%$ & $0.94 \%$ & $1.91 \%$ & $1.13 \%$ & $1.43 \%$ & $1.60 \%$ \\
AU & $1.77 \%$ & $2.92 \%$ & $3.30 \%$ & $1.76 \%$ & $2.45 \%$ & $2.49 \%$ & $1.51 \%$ & $1.28 \%$ & $1.95 \%$ \\
\hline
\end{tabular}

Source: World Bank database. 
Today, we all know how the financial crisis started in the United States, and that is why there is no need to discuss it extensively. What is clear from Table 3 is the decline in GDP in 2009, but since then, GDP has been growing at an average of $2.2 \%$ year on year. Unemployment has also risen to $10 \%$ as a result of the crisis, and debt growth, which now slightly exceeds $100 \%$ of GDP, is a significant problem. The inflation rate fluctuated greatly throughout the period under review, averaging around $1.4 \%$. The lowest except for 2009 was inflation in 2015, which is related to the fall in oil prices.

Canada's economy, as well as some of the other major economies, was also affected by the 2009 crisis - GDP declined, government debt rose above $70 \%$, and the government deficit. However, the following year, it began to shake due to consumer spending and investment in new construction. The slower GDP growth in 2015 and 2016 could be because prices of many commodities fell to historical bottoms, and given that Canada, like Australia, has a strong and important mining industry, it is clear that the commodities market affects its GDP.

The last economy selected is Australia, which has not known the economic recession or crisis for almost 30 years. Good financial health is due to the unusual combination of sectors that drive the economy: agriculture and mining (roughly one-fifth of GDP, including support services), a strong banking sector and financial services, technology development, etc. Australia is a country typical of the mining industry. Looking at the GDP growth rate, we can see that the pace is relatively balanced, with no significant fluctuations. The same can be said about the inflation rate.

\section{Results of statistical tests}

The first method used to detect dependence between independent and dependent variables is correlation analysis. Of the total of 165 relationships examined, only 23 were statistically significant, of which almost no relationship showed any stronger negative or positive dependence between determinants and debt. The strongest link (correlation coefficient -0.15) was found between short-term debt and asset structure in Slovenia. The same relationship (correlation coefficient -0.11) was also confirmed in Slovakia. Both countries have a weak negative link, but this confirms our assumption. Slovak firms reported another five bonds with a correlation coefficient higher than \pm 0.1 a non-debt tax shield combined with total and short-term debt (both -0.12), inflation rate combined with long-term debt (0.11) and asset structure combined with total debt (-0.1). As regards inflation, the results of the non-debt tax shield and asset structure with shortterm debt are in line with our assumptions. Only the asset structure for total debt does not show the link we expected. Overall, however, the correlation results are weak, as many relationships are statistically insignificant, and at the same time, a correlation coefficient of around 0.1 indicates a weak link, so none of our assumptions can be supported by strong results.

Table 5 shows the results of panel regression using the GMM method. At first glance, it is clear that the table does not cover all countries for any form of debt. Countries that we cannot see in the table have not passed the robustness test, and their resulting models have no meaningful value, and it is irrelevant to deal with them. The remaining countries and their models met the Sargan test. Specifically, for total debt, the following values were: CZ 0.003, SK 0.012, PL 0.034, AT 0.000, RO 0.026, AU 0.000; for long- 
term debt: CZ 0.000, SK 0.004, HU 0.000, AT 0.000, RO 0.000, BG 0.000, US 0.000; for short-term debt CZ 0.000, SK 0.025, RO 0.039, BG 0.011, AU 0.025. The remaining countries have fulfilled the assumption and exceeded 0.05 , and the models are therefore relevant and credible. At the same time, in the table, we can see the letter X three times for Slovenian companies, which indicates that inflation is lacking in this model, as its time series in the case of Slovenian was non-stationary. Of course, the data could be adjusted to be stationary, but the resulting numbers would be less and less well explained.

The first relationship examined was the dependence of debt on its lagged value. We can see that in the table, these relations are mostly statistically significant. Negative bonds slightly prevail; however, the resulting coefficients are very low and do not even reach integers, only tenths, and therefore we cannot say that past indebtedness would have any major effect on future indebtedness (decrease or increase depending on the resulting linkage).

In the case of the relationship between profitability and debt in all forms, we expected a negative link. This assumption was fulfilled for Slovenia for all forms of debt as Črnigoj and Mramor (2009), Bulgaria for total debt as Mokhova and Zinecker (2013), Poland for long-term and short-term debt as Nivorozhkin (2005), Delcoure (2007), Mokhova and Zinecker (2013), Růčková (2015b, 2017) and Austria for short-term debt as Cheng and Shiu (2007), Kayo and Kimura (2011). On the other hand, Hungarian and Canadian companies showed a positive link to total and short-term debt as Růčková (2015a, 2015b, 2017). The largest coefficient, -12.23 , can be seen for Slovenia for total debt. The negative link indicates that companies will probably prefer to finance new investments from retained profits from previous years thanks to the likely high profitability, and they will only become indebted when other forms of raising capital are insufficient. This is true for Bulgaria and Poland, which did not have any major problems during the examined period. Negativity can also mean falling profit and rising debt. This link could be used in particular by Austrian and Slovenian companies, as both countries were hit by crises, Slovenia not only once. And so, debt could grow so that companies could keep their businesses alive despite low profits. Hungarian companies did not meet negative expectations regarding profitability. Although the economy was hit hard by the crisis in 2009, the year-on-year GDP growth is quite high, indicating that companies could be profitable and borrow more in the short term to escape the effects of the crisis.

Another link examined is the asset structure and debt. For total and long-term debt, we expected a positive link, which was fulfilled by Slovenian and Australian companies (the highest coefficient - 20.3). This linkage is a typical result of most studies such as Cheng and Shiu (2007), De Jong et al. (2008), Hernádi and Ormos (2010), Kayo and Kimura (2011), Öztekin (2015). For Slovenian companies, the previous studies confirmed a rather negative link - Črnigoj and Mramor (2009) and Mokhova and Zinecker (2013). Unfortunately, the negative assumption has not been confirmed for the US, Canadian (minimum dependency), and Polish companies. The negative link for US companies may be related to the orientation of the US financial system, which is typically oriented towards financial markets where tangible assets cannot be used as collateral. For short-term debt, a negative link was expected because tangible assets cannot normally be used as collateral for short-term loans. This relationship was confirmed by Polish and Canadian companies (minimum dependence), as in the case studies of Bok- 
pin (2009) or Mokhova and Zinecker (2013). In Hungary, Austria, and Slovenia, a positive link has been revealed as Michaelas et al. (1999), Mokhova and Zinecker (2013) or Handoo and Sharma (2014).

\section{Table 6. GMM model}

Total debt

\begin{tabular}{|c|c|c|c|c|c|c|}
\hline & $\operatorname{DER}(-1)$ & $\mathrm{ROA}$ & SA & ODP & GDP & INF \\
\hline $\mathrm{HU}$ & $-0,266^{a}$ & $3,487^{a}$ & 15,195 & $-208,832$ & $-1112,763$ & $-557,920$ \\
\hline $\mathrm{SI}$ & $0,064^{a}$ & $-12,226^{a}$ & $2,042^{a}$ & $-6,169^{a}$ & $17,346^{a}$ & $x$ \\
\hline$B G$ & $-0,022^{a}$ & $-6,863^{a}$ & $-14,861$ & $-17,430$ & $-174,204^{a}$ & $-44,175^{a}$ \\
\hline US & $-0,013^{a}$ & 0,000 & $-3,337^{b}$ & 0,000 & $-39,803^{a}$ & $73,966^{a}$ \\
\hline \multirow[t]{2}{*}{$\mathrm{CA}$} & $-0,003$ & $0,001^{b}$ & $0,000^{b}$ & 0,003 & 6,240 & $-9,319$ \\
\hline & \multicolumn{6}{|c|}{ Long-term debt } \\
\hline$P L$ & $-0,297^{a}$ & $-0,005^{a}$ & $-4,792^{a}$ & $-0,022$ & $-3,840$ & $-0,419$ \\
\hline $\mathrm{SI}$ & $0,009^{a}$ & $-1,315^{a}$ & $0,618^{a}$ & $-0,388^{c}$ & $-0,594^{b}$ & $X$ \\
\hline $\mathrm{CA}$ & $0,049^{a}$ & 0,000 & 0,000 & 0,000 & $-1,650$ & $-6,381^{a}$ \\
\hline \multirow[t]{2}{*}{$\mathrm{AU}$} & $-0,657^{a}$ & 0,231 & $20,311^{\mathrm{b}}$ & $0,733^{c}$ & $-30270,640^{a}$ & $-632,981^{a}$ \\
\hline & \multicolumn{6}{|c|}{ Short-term debt } \\
\hline$P L$ & $-0,504^{a}$ & $-0,007^{a}$ & $-1,563^{a}$ & 1,348 & $-3,856$ & 3,636 \\
\hline $\mathrm{HU}$ & 0,005 & $3,316^{a}$ & $11,764^{b}$ & $-57,357^{a}$ & 23,690 & 118,115 \\
\hline AT & $0,002^{\mathrm{a}}$ & $-0,135^{a}$ & $0,019^{a}$ & $-0,202^{\mathrm{a}}$ & $0,480^{a}$ & $-1,135^{a}$ \\
\hline SI & $0,104^{a}$ & $-7,907^{a}$ & $2,206^{a}$ & $-3,721^{a}$ & $18,545^{a}$ & $X$ \\
\hline US & $0,020^{\mathrm{a}}$ & 0,000 & $-0,446$ & $0,001^{b}$ & $45,490^{b}$ & $41,861^{a}$ \\
\hline $\mathrm{CA}$ & $-0,020^{\mathrm{a}}$ & $0,001^{b}$ & $0,000^{b}$ & $0,003^{b}$ & 5,800 & $-1,948$ \\
\hline
\end{tabular}

Source: Author's calculations based on data from database Orbis.

Symbols: ${ }^{\mathrm{a}},{ }^{\mathrm{b}}$ and ${ }^{\mathrm{c}}$ indicate significance at $1 \%, 5 \%$, and $10 \%$; symbol $\mathrm{X}$ show missing variable in the model because of non-stationary time series.

The non-debt tax shield should have an adverse effect on all forms of debt, as confirmed by results for Slovenian, Austrian (short-term debt), and Hungarian (short-term debt, highest coefficient -57.4) as Wald (1999), Hernádi and Ormos (2012). This effect means that companies that will continually invest in long-term assets where their value dissolves in depreciation, which reduces profit or loss and are their source of financing, will prefer this depreciation benefit and finance their other business activities own sources, which will be increased by depreciation. On the other hand, the Australian (long-term debt), American and Canadian (both for short-term debt) companies were found to be positive, and in particular, the last two mentioned very little dependency between variables. The positive linkage was also shown by Song (2005), AcedoRamírez and Ruiz-Cabestre (2015).

The effect of GDP for at least one type of debt has been demonstrated in several countries, but except for Slovenia for the total debt (positive link), in other cases, exactly the opposite links were found to those expected. GDP has the largest impact on debt for Australian long-term debt companies $-30,270.64$. The negative linkage was revealed by 
Gajurel (2006), Cheng and Shiu (2007), and Bokpin (2009), Jõeveer (2013), for total and short-term debt. For long-term debt, negative link confirmed Cheng and Shiu (2007). On the other hand, the positive relationship was found by Gajurel (2006), Hanousek and Shamshur (2011), Yinusa et al. (2017) for total and long-term debt.

The positive impact in the case of Slovenia means that debt increases or decreases as the business cycle develops. The negative effect is usually explained by the fact that companies are doing so well in economic prosperity and have enough internal resources that they have no reason to use debt financing. This is the case of Bulgaria and US for total debt. As mentioned above, the Bulgarian economy did not have any major fluctuations during the examined period, and therefore, the profitability of the companies was sufficient to cover investments. While the United States was the source of the crisis in 2009, it was knocking off quite quickly, and the economy was recovering again, and as a result, the profits of the companies that preferred this source of funding increased.

The last variable is inflation, which should show a negative relationship with total and long-term debt; a positive relationship with short-term debt. As we can see, the assumptions for total and long-term debt were confirmed by Bulgarian, Canadian, and Australian companies as Cheng and Shiu (2007), Jõeveer (2013), Öztekin (2015), Mursalim and Kusuma (2017). US total debt and Austrian short-term debt companies showed opposite ties than expected.

\section{Conclusion}

This research dealt with the financial structure and its selected determinants. The subject of the research was the mining industry of these eleven economies - the Visegrád Group countries, Bulgaria, Romania, Austria, Slovenia, the United States, Canada, Australia. It was a comparison of selected CEE countries and industry leaders. Selected determinants were profitability, asset structure, non-debt tax shield, macroeconomic development, and inflation. The financial structure was characterized by three forms of debt - short-term, long-term, and total. In total, our assumptions were tested on 19,530 companies during the period 2009-2017. The correlation analysis and the GMM method were methods to help confirm or refute the presumptions. The research aimed to determine the influence of selected determinants on the financial structure of mining companies in eleven selected economies. Three hypotheses for three forms of debt were tested based on a review of earlier studies.

Regarding the results of the correlation analysis, this method revealed several links that would be in line with our assumptions. Still, the correlation coefficients were low to make it clear that a given variable had a given impact on the financial structure of companies.

Therefore, the results of panel regression using the GMM method are more significant. The models for the Czech Republic, Slovakia, and Romania have not passed the robustness test for any of the three forms of debt and therefore have no meaningful value. The remaining countries have undergone a robustness test for at least one form of debt.

The first relationship (regardless of the form of debt) found was between debt and its lagged value. The results were very slightly dominated by negative relationships, which means that if a company used debt financing in the past, it will no longer prefer it in the 
future and will rather try to reduce it. Conversely, positive relationships mean that if a company has been indebted in the past, it will be indebted in the future, and to a greater extent. However, it has to be said that the coefficients were very low, and therefore the effect of the existence and amount of past debt has a minimal effect on future debt.

When dividing debt into total, long-term, and short-term debt, the following paragraphs show the most important determinants for individual countries according to regression analysis. If companies in these countries would look at them and learn to work with them, they could optimize their level of debt.

Overall debt of medium-sized and large mining companies in these countries is most influenced by the following determinants - the positive effect of profitability on the debt of Hungarian and Slovenian companies, the negative effect of GDP growth on the debt of Bulgarian companies, the positive effect of inflation on the debt of US companies.

The following factors have the most significant influence on the long-term debt of medium and large mining companies in these countries - the negative impact of the asset structure on the debt of Polish companies, the negative effect of profitability on the debt of Slovenian companies. GDP growth for the debt of Australian companies.

The short-term debt of mining companies in these countries is most affected by these determinants - the negative impact of profitability on the debt of Slovenian companies, the positive impact of asset structure and the negative impact of non-debt tax shield on the debt of Hungarian companies and the positive effect of the GDP growth rate and the inflation on the debt of US companies.

The following researches could consider the division of companies by size and the addition of other determinants.

Acknowledgements: This research was supported by SGS/7/2018 Analysis of the influence of selected aspects on the financial structure of enterprises in the conditions of Central and Eastern European countries.

Disclosure statement: No potential conflict of interest was reported by the author.

\section{References}

ACEDO-RAMÍREZ, M. A., RUIZ-CABESTRE, F. J. (2014). Determinants of capital structure: United Kingdom versus continental European countries. Journal of International Financial Management \& Accounting, 25(3), 237-270. DOI: $\underline{10.1111 / j i f m .12020}$

AREALLANO, M., BOND, S. (1991). Some tests of specification for panel data: Monte Carlo evidence and an application to employment equations. The Review of Economic Studies, 58(2), 277-297. DOI: $10.2307 / 2297968$

AULOVÁ, R., HLAVSA, T. (2013). Capital structure of agricultural businesses and its determinants. Agris on-line Papers in Economics and Informatics, 5(2), 23-36.

BARJARMOVIĆ, A. (2017). Firm-specific determinants of capital structure - Case of firms in Bosnia and Herzegovina. Advances in Business-Related Scientific Research Journal, 8(2), 13-24. 
BASTOS, D. D. et al. (2009). Determinants of capital structure of publicly-traded companies in Latin America: The role of institutional and macroeconomic factors. Journal of International Finance and Economics, 9(3), 24-39.

BOKPIN, G. A. (2009). Macroeconomic development and capital structure decisions of firms: Evidence from emerging market economies. Studies in Economics and Finance, 26(2), 129-142. DOI: 10.1108/10867370910963055

BREALEY, R. A. et al. (2011). Principles of Corporate Finance. $10^{\text {th }}$ Ed. New York: McGraw-Hill.

CHENG, S. R., SHIU, C. Y. (2007). Investor protection and capital structure: International evidence. Journal of Multinational Financial Management, 17(1), 30-44. DOI: 10.1016/j.mulfin.2006.03.002

ČRNIGOJ, M., MRAMOR, D. (2009). Determinants of capital structure in emerging European economies: Evidence from Slovenian firms. Emerging Markets Finance \& Trade, 45(1), 72-89. DOI: 10.2753/REE1540-496X450105

DE JONG, A. et al. (2008). Capital structure around the world: The roles of firm- and country-specific determinants. Journal of Banking \& Finance, 32(9), 1954-1969. DOI: 10.1016/j.jbankfin.2007.12.034

DELCOURE, N. (2007). The determinants of capital structure in transitional economies. International Review of Economics \& Finance, 16(3), 400-415. DOI: 10.1016/j.iref.2005.03.005

GAJUREL, D. P. (2006). Macroeconomic influences on corporate capital structure. Avalaible from SSRN: https://papers.ssrn.com/sol3/papers.cfm?abstract_id=899049.

GAUD, P., et al. (2003). The capital structure of Swiss companies: An empirical analysis using dynamic panel data. FAME Research Paper No. 68.

HANDOO, A., SHARMA, K. (2014). A study on determinants of capital structure in India. IIMB Management Review, 26(3), 170-182. DOI: 10.1016/j.iimb.2014.07.009

HANOUSEK, J., SHAMSHUR, A. (2011). A stubborn persistence: Is the stability of leverage ratios determined by the stability of the economy? Journal of Corporate F $i$ nance, 17(5), 1360-1376. DOI: 10.1016/j.jcorpfin.2011.07.004

HERNÁDI, P., ORMOS, M. (2010). Capital structure and its choice in Central and Eastern Europe. Acta Oeconomica, 62(2), 229-263.

HERNÁDI, P., ORMOS, M. (2012). What Managers Think of Capital Structure and How They Act: Evidence from Central and Eastern Europe. Baltic Journal of Economics, 12(2), 47-71. DOI: 10.1080/1406099X.2012.10840517

HUONG, P. T. Q. (2018). Macroeconomic factors and corporate capital structure: Evidence from listed joint stock companies in Vietnam. International Journal of Financial Research, 9(1), 31-40. DOI: 10.5430/ijfr.v9n1p31

JÕEVEER, K. (2013). Firm, country and macroeconomic determinants of capital structure: Evidence from transition economies. Journal of Comparative Economics, 41(1), 294-308. DOI: $\underline{10.1016 / j . j c e .2012 .05 .001}$ 
KAYO, E. K., KIMURA, H. (2011). Hierarchical determinants of capital structure. Journal of Banking \& Finance, 35(2): 358-371. DOI: 10.1016/j.jbankfin.2010.08.015

KLAPPER, L. F. et al. (2002). Small- and Medium-Size Enterprise Financing in Eastern Europe. World Bank Policy Research Working Paper No. 2933.

MICHAELAS, N. et al. (1999). Financial policy and capital structure choice in U.K. SMEs: Empirical evidence from company panel data. Small Business Economics, 12(2), 113-130. DOI: $10.1023 / \mathrm{A}: 1008010724051$

MODIGLiANI, F., MILLER, M. H. (1958). The Cost of Capital, Corporation Finance and the Theory of Investment. American Economic Association, 48(3), 261-297.

MOKHOVA, N., ZINECKER, M. (2013). The determinants of capital structure: The evidence from the European Union. Acta Universitatis Agriculturae et Silviculturae Mendelianae Brunensis, 61(7), 2533-2546.

MOKHOVA, N., ZINECKER, M. (2014). Macroeconomic factors and corporate capital structure. Procedia - Social and Behavioral Sciences, 110, 530-540. DOI: $\underline{10.11118 / \text { actaun201361072533 }}$

MURSALIM, M. M., KUSUMA, H. (2017). Capital structure determinants and firms' performance: Empirical evidence from Thailand, Indonesia and Malaysia. Polish Journal of Management Studies, 16(1), 154-164. DOI: 10.17512/pjms.2017.16.1.13

MYERS, S. C. (1984). The capital structure puzzle. Journal of Finance, 39, 575-592. DOI: $\underline{10.2307 / 2327916}$

NIVOROZHKIN, E. (2005). Financing choices of firms in EU accession countries. Emerging Markets Review, 6(2), 138-169. DOI: 10.1016/j.ememar.2004.10.002

ONOFREI, M. et al. (2015). Determinant Factors of Firm Leverage: An Empirical Analysis at Iasi County Level. Procedia Economics and Finance, 20, 460-466.

ÖZTEKIN, Ö. (2015). Capital Structure Decisions around the World: Which Factors Are Reliably Important? The Journal of Financial and Quantitative Analysis, 50(3), 301-323. DOI: $10.1017 /$ S0022109014000660

PINKOVÁ, P. (2012). Determinants of capital structure: Evidence from the Czech automotive industry. Acta Universitatis Agriculturae et Silviculturae Mendelianae Brunensis, 60(7), 217-224. DOI: 10.11118/actaun201260070217

PRŮCHA, I. R. (2014). Instrumental Variables/Method of Moments Estimation. In: FISHER, M. M. and NIJKAMP, P. (ed.) Handbook of Regional Science. Heidelberg: Springer.

RAJAN, R. G., ZINGALES, L. (1995). What do we know about capital structure? Some evidence from international data. The Journal of Finance, 50(5), 1421-1460. DOI: 10.1111/j.1540-6261.1995.tb05184.x

RŮČKOVÁ, P. (2015a). Impact of fixed assets share and profitability on use of debt sources of companies in the building industry in V4 countries. Acta academica karviniensia, 15(2), 122-135. 
RŮČKOVÁ, P. (2015b). Impact of liquidity and profitability on use of debt finance sources of companies in manufacturing industry in V4 countries. Acta academica karviniensia, 15(3), 69-79.

RŮČKOVÁ, P. (2017). Evaluation of profitability impact on selection of financing sources under conditions in Visegrád Group countries in the field of power engineering. Scientific Papers of the University of Pardubice, D(39), 140-150.

SALEHI, M., MANESH, N. B. (2012). A study of the roles of firm and country on specific determinates in capital structure: Iranian evidence. International Management Review, 8(2), 51-62.

SETT, K., SARKHEL, J. (2010). Macroeconomic variables, financial sector development and capital structure of Indian corporate sector during the period 1981-2007. The IUP Journal of Applied Finance, 16(1), 40-56.

SONG, H. S. (2005). Capital structure determinants - An empirical study of Swedish companies. Working paper No. 25, The Royal Institute of Technology, Centre of Excellence for Science and Innovation Studies.

STULZ, R., JOHNSON, H. (1985). An analysis of secured debt. Journal of Financial Economics, 14, 501-521. DOI: 10.1016/0304-405X(85)90024-8

TITMAN, S., WESSELS, R. (1988). The determinants of capital structure choice. The Journal of Finance, 43, 1-19.

VO, X. V. (2017). Determinants of capital structure in emerging markets: Evidence from Vietnam. Research in International Business and Finance, 40, 105-113.

WALD, J. K. (1999). How firm characteristics affect capital structure: An international comparison. The Journal of Financial Research, 22(2), 161-187. DOI: 10.1111/j.14756803.1999.tb00721.x

WEILL, L. (2004). What determinants leverage in transition countries? Czech Journal of Economics and Finance, 54(5-6), 234-242.

YINUSA, O. G. et al. (2017). Macroeconomic determinants of capital structure of firms: Evidence from Nigeria. Journal of Knowledge Globalization, 9(2), 1-21. 